\title{
JAMES RIDDICK PARTINGTON
}

M.B.E., D.SG.

(I 886-I965)

\section{Emeritus Professor of Chemistry in the University of London} (Queen Mary College), rgrg-rg5I.

James Riddick Partington was born at Bolton, Lancashire, on 20 June 1886 . He became a distinguished graduate in the department of chemistry in the faculty of science of Manchester University soon after the famous scientific tradition of Owen's College had added further lustre to Manchester's already notable Victoria University. After obtaining first-class honours in Chemistry, he was made a university scholar and Beyer Fellow, carrying out research in Lapworth's Laboratory at Manchester. Then followed a period of research abroad during which he held an 1851 Exhibition scholarship, working under Nernst in Berlin, on the specific heats of gases. He returned to England in 1913 to a Lectureship in Chemistry at Manchester; on the outbreak of war in I9I4 he joined the army and fortunately his outstanding scientific qualifications were recognized and he was enabled to carry out special investigations in applied chemistry for the Ministry of Munitions, with E. K. Rideal, on water purification and the oxidation of nitrogen, for which work he received the award of the M.B.E. (Military Division). In 1919, at the age of 33, he was appointed to the Chair of Chemistry at Queen Mary College, which he held with distinction for thirty-two years.

Partington's contributions to chemistry fall into three clearly-defined groups. Firstly, his chemical researches. These lay in the inorganic sphere and largely in physical chemistry, e.g. the specific heats of gases begun in Germany under Nernst, followed by further work on the subject in his own professorial department at Queen Mary College. Secondly, his valuable contributions to chemical teaching and chemical interpretation in a notable series of textbooks for students, both elementary and advanced. His Advanced Treatise on Physical Chemistry, published in five volumes between I 949 and I 954, is an outstanding achievement, not only on account of the amazing encyclopaedic knowledge it contains, but for the author's original handling, explanation and interpretation of advanced mathematical techniques made available therein to the physical chemist. Thirdly, his most distinguished work, for which he justly achieved a world-wide reputation and in which his position is unique and likely to remain so, is in the History of Chemistry. His crowning achievement in published work was his magnum opus-A History of Chemistry (Macmillan), publication of which began in I96r but is still incomplete. Volumes II, III and IV have 
been published; at the time of his death Partington was still working on the manuscript of Volume I but a portion of the text had been set up in type. The documentation of this work by a single author is a colossal achievement and words fail one in attempting to describe it. Recently, when I visited him in Cambridge, I asked Partington how he worked on such an impressive task. His description was interesting and revealed his inordinate modesty. He acknowledged that the evacuation of Queen Mary College to Cambridge during the war had been a factor of ease in the process by saving time in travelling to libraries and he then decided to reside permanently in Cambridge. But the physical proximity of libraries was but a partial explanation of an amazing achievement. Partington clearly had disciplined himself for years in the art of documentation and had practised it widely in his earlier publications. His gifts as a great teacher of chemistry were perhaps more impressive as an author and interpreter in writing than in oral description and explanation. As a speaker he was much less emphatic and effective than his intellectual status warranted; he was too modest to do himself justice-undoubtedly a worthy attribute of a scrupulous mind and genuine character, but a defect from a worldly point of view. He spoke softly and at times almost in a whisper, so that even those in the front row at his lectures, or when he presided at meetings, often found it difficult to hear statements of fact, or even more, to follow brilliantly-reasoned argument---surely a pointer to the urgent need for special training and, in individual cases, of technical help in voice production, for all whose professional work in in life involves sustained speaking in public and lecturing to students.

As Secretary it was my privilege to work with Partington when he was President of the Society and to come to know him not only as a colleague but as a friend. He was extremely modest and intensely reserved. The foundation of the Society undoubtedly gave him great satisfaction and his unanimous election as our President, much pleasure. He valued his membership of the Athenaeum where one met him from time to time. He had a dry sense of humour and though in personal judgment he could be blunt, he was never resentful or unjust. His advice was invaluable and he never chafed at calls on his time.

Partington served on the Council of the Chemical Society from 1922 to 1925 . He was the first Chairman of the Society for the Study of Alchemy and Early Chemistry on its foundation in 1937. He was a Foundation Member of the British Society for the History of Science and served it as Vice-President, I947-49, and as President, I 949-5 I ; in 1963 the Society conferred upon him its highest honour-Honorary Membership. In I96I, Partington received the Dexter Award of the Division of the History of Chemistry of the American Chemical Society and shortly before his death the award of the Sarton Medal of the American History of Science Society. 
It is sad to have to record the fact-but one feels it a duty to mention it - that no British university was moved to honour a British scholar of world renown with an Honorary Degree; nor did any college in the two universities within which his main life's work was done think of awarding him an Honorary Fellowship. Fortunately The Times partly redeemed the situation after his death with an excellent obituary notice.

\section{F. H. C. Butler}

\section{ACADÉEIE DES SCIENCES}

\section{TERGENTENARY GELEBRATIONS}

The first meeting of the French Academie des Sciences was held on 22 December 1666 in the King's library in Paris. It has been decided that the summer months are more suitable for the organization of celebrations involving international representation and the tercentenary celebrations are accordingly being held in Paris from 5 to 10 June 1966. The programme includes many receptions and several visits, including one to the National Observatory.

\section{JOHN DALTON BICENTENARY GELEBRATIONS}

To commemorate the bicentenary of the birth of John Dalton (born 6 September I766), celebrations are being held in Manchester from 19-23 September 1966. Some twenty speakers will be giving lectures on different aspects of the origins and implications of Dalton's contributions to science. Further details from Secretariat: 36 George Street, Manchester I. 